\title{
Epidemiology of Okra Yellow Vein Mosaic Virus (OYVMV) and Its Management through Tracer, Mycotal and Imidacloprid
}

\author{
Muhammad Irfan Ali, Muhammad Aslam Khan, Abdul Rashid, Muhammad Ehetisham-ul-haq*, \\ Muhammad Talha Javed, Muhammad Sajid
}

Department of Plant Pathology, University of Agriculture, Faisalabad, Pakistan.

Email: * plant.uaf@gmail.com

Received September $15^{\text {th }}, 2012$; revised October $17^{\text {th }}, 2012$; accepted November $20^{\text {th }}, 2012$

\begin{abstract}
Field trials were conducted to evaluate the epidemiological factors of okra yellow vein mosaic virus (OYVMV). Four varieties of okra were subjected to screening and evaluation of the chemicals. The variety Saloni F1 was highly resistant while Subz Pari was moderately resistant. Diksha was the tolerant variety while Lush Green was moderately susceptible. The chemical Imidacloprid was most effective to control whitefly population and okra yellow vein mosaic virus (OYVMV). Correlation of environmental factors (maximum and minimum temperature, relative humidity and rainfall) with percent plant infection of okra yellow vein mosaic virus (OYVMV) was also determined. There was a significant correlation between environment and disease severity.
\end{abstract}

Keywords: Epidemiology; Imidacloprid; Okra (Abelmoschus esculentus L. Moench); Okra Yellow Vein Mosaic Virus (OYVMV) and Whitefly

\section{Introduction}

Okra (Abelmoschus esculentus L. Moench) is an important and extensively grown vegetable crop. It is placed in placed in Malvaceae family. It is thought that its origin is tropical Africa. Okra is a vital crop of tropical and sub-tropical regions of the world [1-3]. It is assumed that it has been grown in agro Asian countries since ancient time but also grown in southern parts of United States like Georgia, Florida, Texas and Alabama [4]. Okra is sown for several purposes [5]. It fruits are used as a boiled vegetable [6] and stem is used for making papers. Okra green fruits have high nutritional contents like carbohydrate, protein, fats, vitamins and minerals [6-10]. As a medicine it is used as a medicine to replace plasma and to expand blood volume [11]. Okra requires a long and warm growing season for optimum growth and development. In the plains areas two crops of okra (early \& late) are cultivated. Its average yield in Pakistan is $800-1000 \mathrm{~kg} \cdot \mathrm{ha}^{-1}$ [12] which is comparatively very low as compared to USA which is approximately $17,000-20,000 \mathrm{~kg} \cdot \mathrm{ha}^{-1}[13]$. Okra is chiefly attacked by numbers of viruses, fungi, bacteria, phytoplasma, nematodes and insect pests attack this crop $[14,15]$. Crop pests reduced the yield up to $20 \%$ $30 \%$, and in case of severe infestation loss may be up to

${ }^{*}$ Corresponding author.
$80 \%-90 \%$ [14]. Okra Yellow Vein Mosaic is the most serious disease of okra and is transmitted by white fly (Bemisia tabaci Gen.) [10,16]. Infection rate may reaches up to $100 \%$ but in field yield loss ranges between $50 \%$ and $94 \%$ depending on the stage of crop growth [17]. If infection occurs in first 20 days after germination, the growth of plants become stop, few leaves and fruits are formed and yield loss reaches up to 94\% [18]. As plant's age increases the rate of yield loss decreases due to pathogen. Plants of 50 and 65 days old suffer a loss of 84 and $49 \%$, respectively $[9,18]$.

The objective of this study was to evaluate different okra cultivars against OYVMV under field condition and to determine the correlation of environmental factors with OYVMV disease severity and whitefly population density on okra varieties.

\section{Materials \& Methods}

The experiment was conducted in the research area of Department of Plant Pathology, University of Agriculture, Faisalabad. Four different okra varieties Subz Pari, Saloni F1, Diksha and Lush Green were sown. Each variety was replicated thrice having row to row and plant to plant distance 60 and $20 \mathrm{~cm}$ respectivly. The experiment was conducted in a randomized complete block design. Na- 
tural inoculum was relied upon for infection of OYVMV. The disease on each of test entries was assessed by Ali and Khan's scale [14].

\begin{tabular}{lc}
\hline Rating Scale & Severity Range (\%) \\
\hline 0) Immune & $0 \%$ \\
1) Highly resistant & $1 \%-10 \%$ \\
2) Moderately resistant & $11 \%-25 \%$ \\
3) Tolerant & $26 \%-50 \%$ \\
4) Moderately susceptibility & $51 \%-60 \%$ \\
5) Susceptibility & $61 \%-70 \%$ \\
6) Highly susceptibility & $71 \%-100 \%$ \\
\hline
\end{tabular}

\subsection{Epidemiological Data}

The data on different environmental conditions (maximum temperature, minimum temperature, relative humidity, rainfall, and wind velocity) during growth period of the crop were obtained from the department of Crop Physiology, University of Agriculture, Faisalabad, Pakistan.

\subsection{Chemical Treatment for Whitefly}

The data on the white fly population were recorded, early in the morning, 24 hours before spray and then 48 hours after spray. Three plants from each row were selected at random and populations of white fly were recorded from upper, middle and lower leaves of the plants.

Treatments were applied for the control of vector (Bemisia tabaci) when it reached at the economic thresh hold level (3 - 4 white fly/leaf). Following treatments were applied randomly on each block of Okra line/varieties.

1) Mycotal $100 \mathrm{~g} /$ acre

2) Imidacloprid @ $200 \mathrm{ml} / \mathrm{acre}$

3) Tracer @ 40 - $60 \mathrm{ml} / \mathrm{acre}$

4) Control

\subsection{Statistical Analysis}

The data on the whitefly population and percent plant infection were subjected to statistical analysis using RCBD factorial design. ANOVA was used to determine the effect of insecticides on the white fly population and OYVMV incidence and the treatment means when compared by LSD test [19]. To determine the relation of environment with white fly population and percent Plant Infection data were subjected to the correlation and regression.

\section{Results \& Discussion}

The response of varieties varied greatly regarding their level of resistance and susceptibility (Table 1). Saloni f1 graded as highly resistant, which exhibited $9.96 \%$ plant infection in the category of $1 \%-10 \%$ infection. Subz Pari gave $14.85 \%$ plant infection and graded as moderately resistant in the category of $11 \%-25 \%$ infection. Diksha gave $45.67 \%$ plant infection and graded as tolerant in the category of $26 \%-50 \%$ infection. Lush Green was moderately susceptible and showed $59.85 \%$ plant infection. [20] screened six varieties of bhindi for resistance to YVMV in the rainy and summer seasons. The incidence of OYVMV was higher during the rainy season. Arka Anamika was highly resistant, Arka Abhag resistant Parbhani kranti and V-6 were moderately resistant to disease. Others were susceptible or highly susceptible. [21] conducted field trials in which 7 okra cultivars were evaluated for growth and yield characteristics and virus resistance. Arka anamika and Arka Abhag were the most suitable yellow vein mosaic virus resistant okra for commercial cultivation. [22] studied the genetics of yellow vein mosaic virus resistance in okra based on 9 generations derived from crosses involving resistant and susceptible cultivars. Virus resistance was evaluated assumeing the qualitative and quantitative nature of inheritance. Additive gene effects were more significant than dominance gene effects.

\subsection{Correlation of Environmental Factors with Yellow Vein Mosaic Virus Disease}

The role of environmental conditions cannot be denied in case of creation of epiphytotic situations in plant diseases. Each parameter of environmental factor plays its role in reducing or enhancing of pathogenic activity as well as vectors especially insect vectors.

Different environment variables (max. temperature, min. temperature and avg. temperature) significantly influenced the disease incident. Their relationship was explained by linear regression model and represented graphically.

\subsection{Max. Temperature vs Percent Plant Infection}

Max. Temperature had significant correlation with percent plant infection of OYVMV on all four varities. Diksha and Solani F1 showed the highly significant relationship with percent plant infection (Table 2). The rate of percent plant infection decreased with an increase in max. Temperature from $35^{\circ} \mathrm{C}-41^{\circ} \mathrm{C}$. relationship of percent plant infection with max. Temperature was best explained by $-0.95,-0.98,-0.98$ and -0.97, r. values respectively in four varieties in (Figure 1).

\subsection{Min. Temperature vs Percent Plant Infection}

Min. temperatures negatively influence the percent plant infection of OYVMV, non significant relationship was 
Table 1. Response of OKRA varieties to yellow vein mosaic virus.

\begin{tabular}{|c|c|c|c|c|}
\hline Serial \# & Cultivars & Means of disease rating $\%$ & Severity rating & Level of resistant/susceptible \\
\hline 1 & Saloni F1 & 9.96 & 1 & Highly resistant \\
\hline 2 & Subz Pari & 14.85 & 2 & Moderately resistant \\
\hline 3 & Diksha & 45.67 & 3 & Tolerant \\
\hline 4 & Lush Green & 59.85 & 4 & Moderately susceptible \\
\hline
\end{tabular}

Table 2. Correlation of environmental factors with percent plant infection on four varieties.

\begin{tabular}{|c|c|c|c|c|c|c|}
\hline \multirow{2}{*}{ Varieties } & \multicolumn{2}{|c|}{ Temperature } & \multirow{2}{*}{ Average temperature } & \multirow{2}{*}{ Relative humidity } & \multirow{2}{*}{ Rain fall } & \multirow{2}{*}{ Wind speed } \\
\hline & Max. & Min. & & & & \\
\hline Subz Pari & $-0.95^{*}$ & -0.86 & -0.91 & 0.85 & 0.62 & -0.68 \\
\hline Saloni F1 & $-0.98^{* *}$ & $-0.96^{*}$ & $-0.98^{* *}$ & 0.89 & 0.79 & -0.63 \\
\hline Diksha & $-0.98^{* *}$ & -0.91 & $-0.95^{*}$ & 0.89 & 0.69 & -0.63 \\
\hline Lush Green & $-0.97^{*}$ & -0.89 & -0.93 & 0.89 & 0.67 & -0.63 \\
\hline
\end{tabular}

${ }^{* *}$ Highly Significant; ${ }^{*}$ Significant; NS = Non Significant.

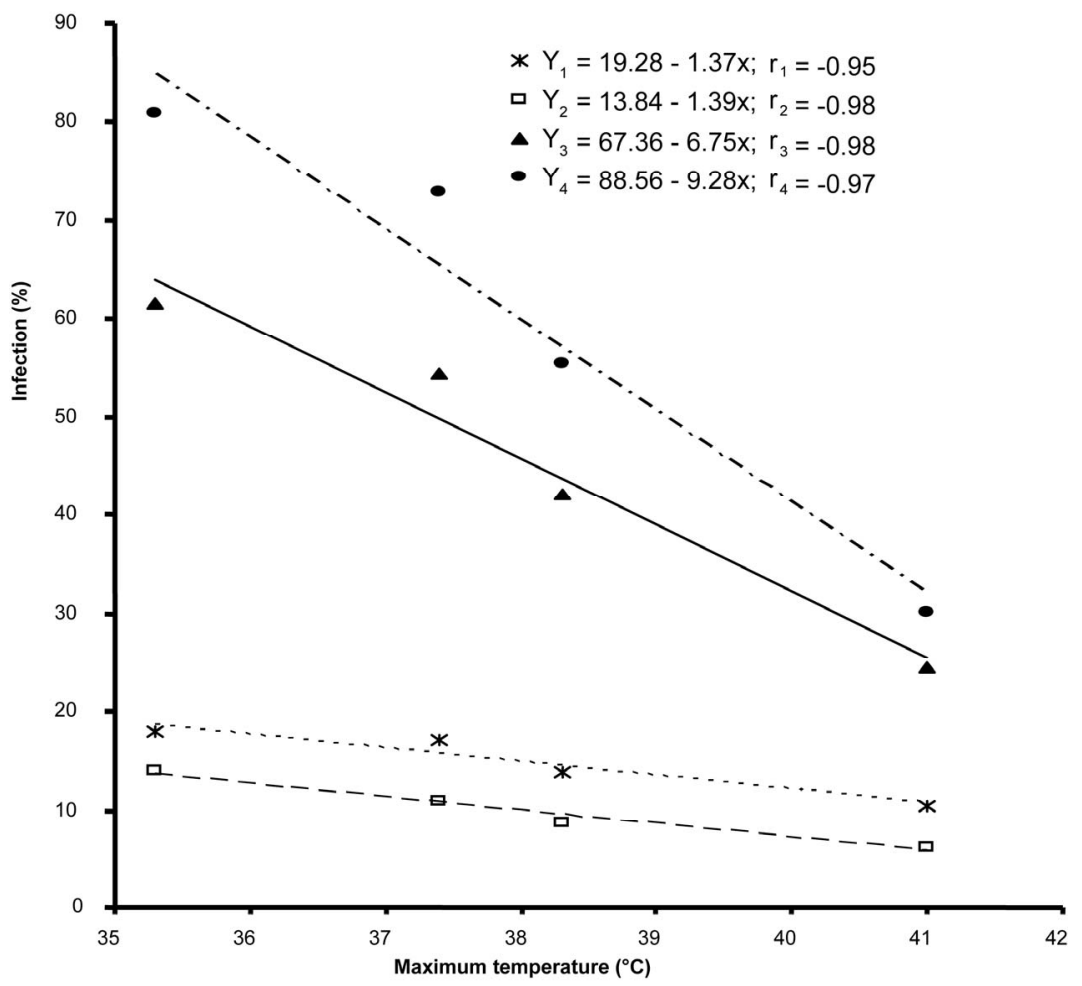

Figure 1. Relationship of Max. temperature with percent plant infection recorded on four varieties $\mathbf{Y}_{1}$ (Subz Puri), $\mathbf{Y}_{2}$ (Saloni F1), $Y_{3}$ (Diksha), $Y_{4}$ (Lush Green), respectively.

found except in Solani F1 it was significant. It was observed that with an increase in min. temperature percent plant infection decrease (Figure 2).

\subsection{Avg. Temperature vs Percent Plant Infection}

A significant correlation was found between percent plant infection and avg. temperature. The percent plant infection decrease with increase in avg. temperature from $30^{\circ} \mathrm{C}$ to $33.5^{\circ} \mathrm{C}$. This relationship of percent plant infection with avg. temperature was explained by -0.91 , $-0.98,-0.95$ and $-0.93 \mathrm{r}$. values respectively in four varieties. This relationship is represented in (Figure 3).

\subsection{Correlation of Environmental Conditions with Whitefly Population on Four Varieties}

The correlation of whitefly population with maximum temperature on Subz Pari, Diksha, Lush Green was sig- 


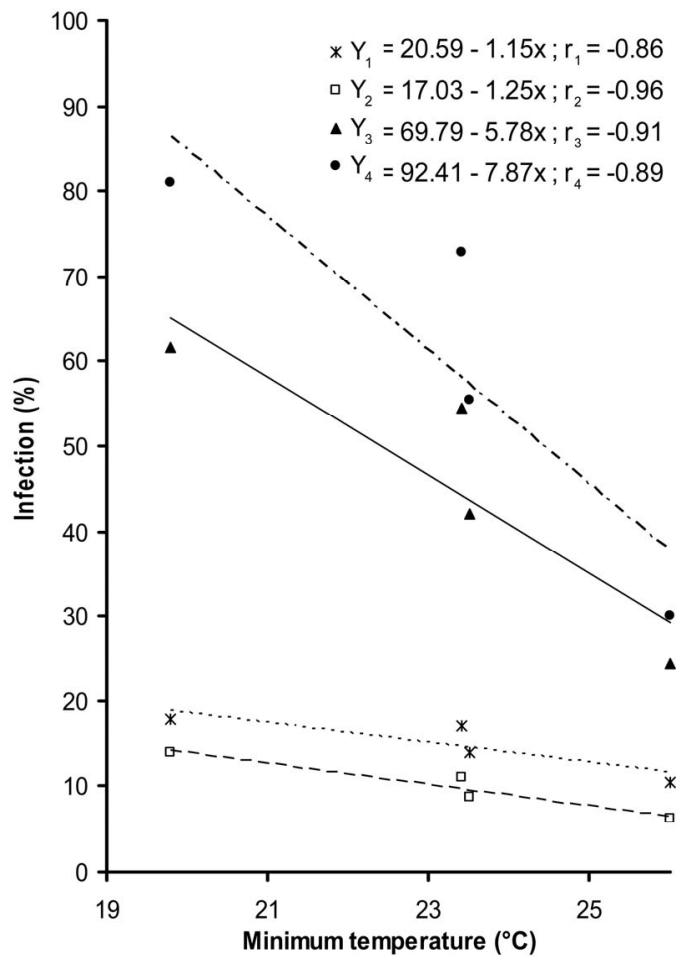

Figure 2. Relationship of Min. temperature with percent plant infection recorded on four varieties $Y_{1}$ (Subz Puri), $Y_{2}$ (Saloni F1), $\mathbf{Y}_{3}$ (Diksha), $\mathbf{Y}_{4}$ (Lush Green), respectively.

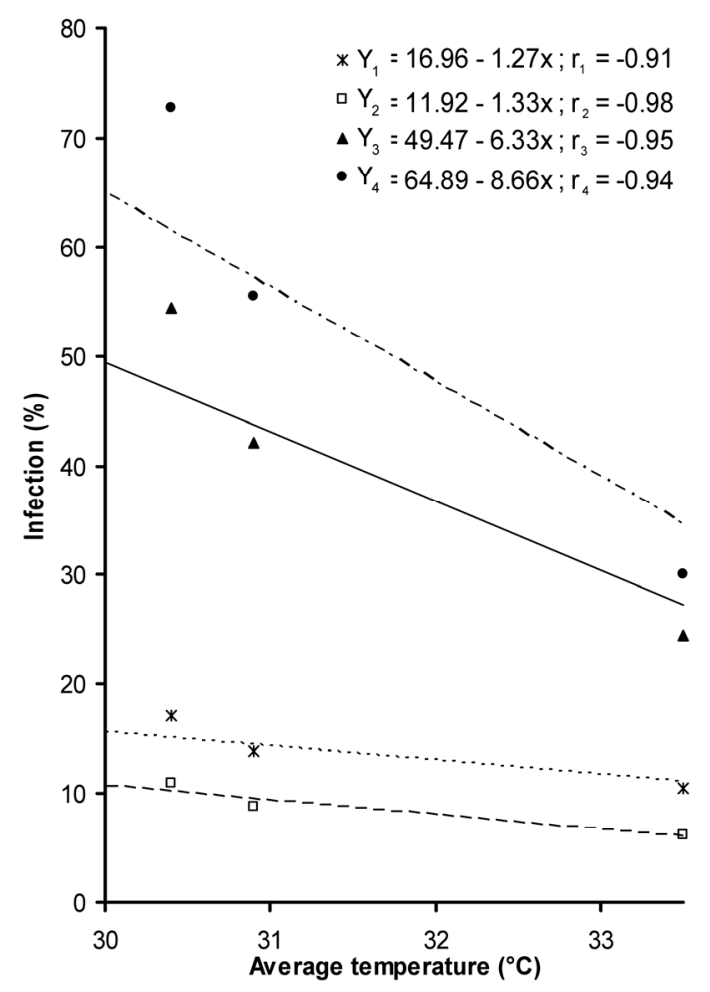

Figure 3: Relationship of Avg. temperature with percent plant infection recorded on four varieties $Y_{1}$ (Subz Puri), $Y_{2}$ (Saloni F1), $Y_{3}$ (Diksha), $Y_{4}$ (Lush Green), respectively.
Table 3. Correlation of environmental factors with whitefly population on four varieties.

\begin{tabular}{ccccccc}
\hline \multicolumn{7}{c}{ Environmental Conditions } \\
\hline Varieties & \multicolumn{2}{c}{ Temperature } & \begin{tabular}{c} 
Average \\
\cline { 2 - 7 }
\end{tabular} & $\begin{array}{c}\text { Relative } \\
\text { Max. }\end{array}$ & Min. & Rain \\
temperature & humidity & fall & $\begin{array}{c}\text { Wind } \\
\text { speed }\end{array}$ \\
\hline Subz pari & $-0.98^{* *}$ & $-0.97^{*}$ & $-0.98^{* *}$ & $0.98^{* *}$ & 0.86 & -0.38 \\
Saloni F1 & -0.88 & -0.92 & -0.91 & $0.98^{* *}$ & 0.90 & -0.08 \\
Diksha & $-0.96^{*}$ & -0.88 & -0.93 & 0.87 & 0.65 & -0.66 \\
Lush green & $-0.97^{*}$ & -0.89 & -0.94 & 0.85 & 0.67 & -0.70 \\
\hline${ }^{* *}$ Significant $=\mathrm{p}<0.05,{ }^{*}$ highly significant $=\mathrm{p}<0.01$, non-significant $=\mathrm{p}>0$.
\end{tabular}

Table 4. Effect of chemicals on whitefly population on okra varieties.

\begin{tabular}{cc}
\hline TREATMENTS & WHITE FLY PAPULATION \\
\hline T1 (Mycotel) & $03.74 \mathrm{~b}$ \\
T2 (Imidacloprid) & $01.97 \mathrm{~d}$ \\
T3 (Tracer) & $02.90 \mathrm{c}$ \\
T4 (Control) & $09.65 \mathrm{a}$ \\
\hline
\end{tabular}

nificant while on Solani F1 it was non significant. The correlation of whitefly population with minimum temperature on Diksha, Lush green and Solani F1 was non significant but on Subz Pari, it was significant. This may be attributed to differential response of varieties to environmental conditions. Relative humidity showed significant correlation with whitefly population on Subz pari and Solani F1 while for Diksha and Lush green, it was non sgnificant. Other variables such as Rain fall and Wind speed were non significant (Table 3).

[23] found that hot weather with little or no rainfall was conducive for disease progress of OYVMV and also for multiplication of Bemisia tabaci. Cooler weather with high relative humidity and rainfall were detrimental to whitefly population and spread.

[24] checked the effect of planting and chemicals on the incidence and spread of yellow vein mosaic of okra. They found that the disease incidence reached comparable levels in both treated and untreated plots after $45-60$ days of sowing and rates of disease increase were similar. In case of time of sowing, incidence was lower in May sowing than those of June or August.

\subsection{Effect of Chemicals on Whitefly Population on Okra Varieties}

Three insecticides "Mycotel Tracer and Imidacloprid" were used to control the white fly population. Among them Imidacloprid showed effective results (Table 4).

\section{Conclusion}

Regarding this study it was concluded that out of six en- 
vironmental variables, Wind speed and rainfall had statistically non significant correlation with OYVMV and whitefly population. Decrease in minimum temperature was conducive for disease development while increase in relative humidity was detrimental to whitefly population. These findings can be used to build up a disease prediction model.

\section{REFERENCES}

[1] B. Akinyele and O. Osekita, "Correlation and Path Coefficient Analyses of Seed Yield Attributes in Okra (Abelmoschus esculentus (L.) Moench)," African Journal of Biotechnology, Vol. 5, No. 14, 2009, pp. 1330-1336.

[2] A. Alam and M. Hossain, "Variability of Different Growth Contributing Parameters of Some Okra (Abelmoschus Esculentus L.) Accessions and Their Interrelation Effects on Yield," Journal of Agriculture \& Rural Development, Vol. 6, No. 1, 2008, pp. 25-35.

[3] D. Wammanda, A. Kadams and P. Jonah, "Combining Ability Analysis and Heterosis in a Diallel Cross of Okra (Abelmoschus esculentus L. Moench)," African Journal of Agricultural Research, Vol. 5, No. 16, 2010, pp. 21082115.

[4] H. C. Thompson and W. C. Kelley, "Vegetables Crops," McGraw Book Co. Inc., New York, 1937.

[5] Z. Qhureshi, "Breeding Investigation in Bhendi (Abelmoschus esculentus (L.) Moench)," University of Agricultural Sciences, 2007.

[6] W. J. Lamont Jr., "Okra-A Versatile Vegetable Crop," HortTechnology, Vol. 9, No. 2, 1999, pp. 179-184.

[7] D. B. Haytowitz and R. H. Matthews, "Composition of Foods: Vegetables and Vegetable Products: Raw, Processed, Prepared," Agriculture Handbook, 1984.

[8] A. Baloch, S. Qayyum and M. Baloch, "Growth and Yield Performance of Okra (Abelmoschus esculentus L.) Cultivars," Gomal University Journal of Research, Vol. 10, 1990, p. 191.

[9] S. Ali, M. Khan, A. Habib, S. Rasheed and Y. Iftikhar, "Management of Yellow Vein Mosaic Disease of Okra through Pesticide/Bio-Pesticide and Suitable Cultivars," International Journal of Agriculture and Biology, Vol. 7, No. 1, 2005, pp. 145-147

[10] A. Fajinmi and O. Fajinmi, "Incidence of Okra Mosaic Virus at Different Growth Srages of Okra Plants (Abelmoschus esculentus L. Moench) under Tropical Condition," Journal of General and Molecular Virology, Vol. 2, No. 1, 2006, pp. 28-31.

[11] C. Lengsfeld, F. Titgemeyer, G. Faller and A. Hensel, "Glycosylated Compounds from Okra Inhibit Adhesion of Helicobacter pylori to Human Gastric Mucosa," Journal of Agricultural and Food Chemistry, Vol. 52, No. 6, 2004, pp. 1495-1503. doi:10.1021/jf030666n

[12] Anonymous, "Fruits, Vegetable and Condiments Statistics of Pakistan," Ministry of Food, Agriculture Livestock, Food, Agric, Livestock, 2002.

[13] T. J. Talbert, "Growing Fruit and Vegetable Crops," Soil Science, Vol. 76, No. 5, 1953, p. 402. doi:10.1097/00010694-195311000-00016

[14] S. Ali, M. Khan, A. H. S. Rasheed and Y. Iftikhar, "Correlation of Environmental Conditions with Okra Yellow Vein Mosaic Virus and Bemisia tabaci Population Density," International Journal of Agriculture and Biology, Vol. 7, No. 1, 2005, pp. 142-144.

[15] T. Prakasha, P. MS and B. VI, "Survey for Bhendi Yellow Vein Mosaic Disease in Parts of Karnataka," Karnataka Journal of Agricultural Sciences, Vol. 23, 2010, pp. 658-659.

[16] G. A. M. Ghanem, "Okra Leaf Curl Virus: A Monopartite Begomovirus Infecting Okra Crop in Saudi Arabia," 2003.

[17] K. Sastry and S. Singh, "Effect of Yellow Vein Mosaic Virus Infection on Growth and Yield of Okra Crop (India)," Indian Phytopathology, Vol. 27, No. 3, 1975, pp. 294-297.

[18] K. S. M. Sastry and S. J. Singh, "Effect of Yellow Vein Mosaic Virus Infection on Growth and Yield of Okra Crop," Indian Phytopathology, Vol. 27, No. 3, 1974, pp. 294-297.

[19] R. G. D. Steel, J. H. Torrie and D. Dickey, "Principles and Procedures of Statistics. A Biometrical Approach," McGraw Hill Book Co. Inc., New York, 1997.

[20] R. B. S. Sangar, "Field Reaction of Bhindi Varieties to Yellow Vein Mosaic Virus," Indian Journal of Virology, Vol. 13, No. 2, 1997, pp. 131-134.

[21] A. Sannigrahi and K. Choudhury, "Evaluation of Okra Cultivars for Yield and Resistance to Yellow Vein Mosaic Virus in Assam," Environment and Ecology, Vol. 16, No. 1, 1998, pp. 238-239.

[22] V. Vashisht, B. Sharma and G. Dhillon, "Genetics of Resistance to Yellow Vein Mosaic Virus in Okra," Crop Improvement, Vol. 28, No. 2, 2001, pp. 218-225.

[23] J. S. Singh, "Etiology and Epidemiology of Whitefly Transmitted Virus Disease of Okra," Plant Disease Research, Vol. 5, 1990, pp. 64-70.

[24] G. Dahal, F. P. Neupane and D. R. Baral, "Effect of Planting and Insecticide and Spread of Yellow Vein Mosaic of Okra in Nepal," International Journal of Tropical Plant Diseases, Vol. 10, No. 1, 1992, pp. 109-124. 